\title{
THE PERSIANS
}

Homa Katouzian is Iranian by birth, with an academic background in economics and the social sciences. He currently teaches Iranian history and literature at St Antony's College and the Oriental Institute, University of Oxford. He is the editor of the journal Iranian Studies and the author of numerous academic monographs and articles about Iran and its literature. 



\title{
HOMA KATOUZIAN
}

\author{
$\infty$ \\ THE \\ PERSIANS \\ Ancient, Mediaeval \\ and Modern Iran
}




\section{Copyright (C) 2009 Homa Katouzian}

First printed in paperback 2010

The right of Homa Katouzian to be identified as author of this work has been asserted by him in accordance with the Copyright, Designs and Patents Act 1988.

All rights reserved. This book may not be reproduced in whole or in part, in any form (beyond that copying permitted by Sections 107 and 108 of the U.S. Copyright Law and except by reviewers for the public press) without written permission from the publishers.

For information about this and other Yale University Press publications, please contact:

U.S. Office: sales.press@yale.edu yalebooks.com

Europe Office: sales@yaleup.co.uk www.yalebooks.co.uk

Set in Minion Pro by IDSUK (DataConnection) Ltd.

Printed in Great Britain by MPG Books, Bodmin, Cornwall

Library of Congress Cataloging-in-Publication Data

Katouzian, Homa.

The Persians : ancient, medieval, and modern Iran / Homa Katouzian.

p. $\mathrm{cm}$.

Includes bibliographical references and index.

ISBN 978-0-300-16932-4 (alk. Paper) 1. Iran-History. I. Title.

DS272.K375 2009

955-dc22

A catalogue record for this book is available from the British Library.

ISBN 978-0-300-16932-4 (pbk) 